\title{
Correction
}

Contrib Mineral Petrol (1981) 76:440-454

\section{Diffusion in Silicate Minerals and Glasses: A Data Digest and Guide to the Literature}

Robert Freer

A number of errors arose during the rationalization and compilation of the tabulated diffusion data. The correct results are shown below.

\begin{tabular}{lll}
\hline Data & Location & Correct value \\
\hline Constant $\mathrm{k}$ & Table 1 & $k=8.612 \times 10^{-5} \mathrm{eV} \mathrm{K}^{-1}$ \\
${ }^{18} \mathrm{O}$ diffusion in phlogopite & Table 2, ref. 49 & $D_{0}=1.03 \times 10^{-13} \mathrm{~m}^{2} \mathrm{~s}^{-1}$ \\
${ }^{7} \mathrm{Li}$ diffusion in albite & Table 3, ref. 147 & $D_{0}=2.03 \times 10^{-5} \mathrm{~m}^{2} \mathrm{~s}^{-1}$ \\
${ }^{7} \mathrm{Li}$ diffusion in LS $(33,67)$ & Table 3, ref. 182 & $Q=75 \mathrm{~kJ} \mathrm{~mol}^{-1}$ \\
\hline
\end{tabular}

Received February 11, 1982

Announcement

\section{7th International Geological Congress}

The 27th International Geological Congress will be held in Moscow, USSR, August 4-14, 1984. The First Circular is now available from:

The Organizing Committee of the 27th IGC

Institute of the Lithosphere

Staromonetniy 22

Moscow 109180, USSR

To receive the Second Circular the application form included in the First Circular must be returned to the above address before August 1, 1982. 